\title{
Translocation of Oxathiapiprolin in Bell Pepper Plants and Systemic Protection of Plants Against Phytophthora Blight
}

Tianli Qu, Chemistry and Pharmacy College, Qingdao Agricultural University, Shandong 266109, China; and Department of Plant Pathology, University of Georgia, Tifton 31794; Timothy L. Grey, Department of Crop and Soil Sciences, University of Georgia; and Alexander S. Csinos, and Pingsheng Ji, Department of Plant Pathology, University of Georgia, Tifton 31794

\begin{abstract}
Qu, T., Grey, T. L., Csinos, A. S., and Ji, P. 2016. Translocation of oxathiapiprolin in bell pepper plants and systemic protection of plants against Phytophthora blight. Plant Dis. 100:1931-1936.

Production of bell pepper is seriously affected by Phytophthora capsici, the causal agent of Phytophthora blight. Limited approaches are available for effective management of the disease. Oxathiapiprolin is a fungicide recently registered in the United States that suppressed $P$. capsici and reduced Phytophthora blight on bell pepper significantly in our previous studies. It is unknown whether oxathiapiprolin translocates in bell pepper plants systemically after application. Experiments were conducted to determine uptake of oxathiapiprolin by bell pepper plants and its systemic movement in the plant. Quantification of oxathiapiprolin in plant tissues was conducted by high-performance liquid chromatography (HPLC) that detected the compound sensitively and selectively. Percentage of recovery of oxathiapiprolin from plant tissues was calculated by comparing the quantities in plant tissues determined by HPLC with known quantities of the compound added to the plant tissues. Recovery rates of oxathiapiprolin from pepper plant tissues

ranged from 87.0 to $119.3 \%$. When oxathiapiprolin was applied to roots of bell pepper plants grown in hydroculture, the compound was detected in the root within $4 \mathrm{~h}$ and in the cotyledon, first true leaf, and second true leaf within $8 \mathrm{~h}$. It was detectable in the top new leaf $48 \mathrm{~h}$ after application to the root. In greenhouse studies with bell pepper plants grown in pots, oxathiapiprolin was applied as a soil drench at 100 and $400 \mu \mathrm{g} / \mathrm{ml}$. The compound was detected in the root within 3 days and in the stem and first true leaf within 6 days when applied at $100 \mu \mathrm{g} / \mathrm{ml}$. It was detected in the root, stem, first true leaf, and top new leaf within 3 days when applied at $400 \mu \mathrm{g} / \mathrm{ml}$. Phytophthora blight on pepper foliage was significantly reduced when oxathiapiprolin was applied as a soil drench at 100 or $400 \mu \mathrm{g} / \mathrm{ml}$ under greenhouse conditions. This is the first report indicating systemic movement of oxathiapiprolin in pepper plants that provides useful information for designing fungicide application programs for effective management of the disease.
\end{abstract}

Phytophthora blight, caused by Phytophthora capsici, is responsible for significant yield and quality reduction in the production of vegetable crops worldwide (Erwin and Ribeiro 1996; Hausbeck and Lamour 2004; Sanogo and Ji 2013). The pathogen has a wide host range and vegetable crops seriously affected in the southeastern United States include squash (Cucurbita pepo), pepper (Capsicum annuum), watermelon (Citrullus lanatus), zucchini (Cucurbita pepo var. cylindrica), cucumber (Cucumis sativus), and eggplant (Solanum melongena). Bell pepper is among the most susceptible crop that is affected by the disease in both spring and fall growing seasons in Georgia. In addition to root and crown rot, pepper foliage is commonly affected, causing stem lesions and leaf blight that may result in significant growth and yield reduction.

$P$. capsici is a soilborne pathogen that is difficult to control. Host resistance and crop rotation are recommended strategies for control of soilborne diseases. Some bell pepper cultivars with moderate levels of resistance to Phytophthora blight are commercially available but they usually produce smaller fruit and are not commonly adopted by Georgia growers (Dunn et al. 2013; Foster and Hausbeck 2010; Sanogo and Ji 2012). A challenge in managing Phytophthora blight is that the pathogen survives in irrigation water sources and may produce oospores that can survive in soil for years (Erwin and Ribeiro 1996; Gevens et al. 2007; Krober 1980; Wang et al. 2009). Both mating types of the pathogen have been discovered in major vegetablegrowing areas in Georgia; therefore, oospores are likely produced in the fields (Yin et al. 2012). Contaminated irrigation water and longterm survival of oospores in the absence of hosts of the pathogen reduce efficacy of crop rotation for managing the disease.

Corresponding author: P. Ji; E-mail: pji@uga.edu

Accepted for publication 6 May 2016.

http://dx.doi.org/10.1094/PDIS-03-16-0370-RE

(C) 2016 The American Phytopathological Society
Application of fungicides is the most common method used by vegetable producers to manage Phytophthora blight. A few new fungicides used for control of $P$. capsici include fluopicolide, mandipropamid, and dimethomorph. Isolates of $P$. capsici from different vegetable production areas are sensitive to fluopicolide, and application of fluopicolide reduced Phytophthora blight on pepper, squash, cucumber, tomato (S. lycopersicum), and watermelon under greenhouse and field conditions (Cerkauskas et al. 2015; Foster and Hausbeck 2010; Jackson et al. 2010; Keinath and Kousik 2011; Kousik et al. 2011; Matheron and Porchas 2015; Meyer and Hausbeck 2013). Fluopicolide is a fungicide in the benzamide and pyridine class that delocalizes spectrin-like proteins (Toquin et al. 2008).

Mandipropamid is another commonly used fungicide for control of $P$. capsici, which is in the mandelamide class and inhibits synthesis of lipids and cell membrane (Kuck and Gisi 2008). Mandipropamid inhibited different asexual life stages of $P$. capsici and was effective in reduction of Phytophthora blight on pepper, tomato, and cucurbits (Cerkauskas et al. 2015; Foster and Hausbeck 2010; Jackson et al. 2012; Ji et al. 2011; Kousik et al. 2011; Matheron and Porchas 2015; Meyer and Hausbeck 2013). Dimethomorph belongs to the mandelamide class and has a mode of action similar to that of mandipropamid (Kuck and Gisi 2008; Kuhn et al. 1991). A number of studies indicated that dimethomorph was active in suppression of $P$. capsici and reduction of Phytophthora blight on pepper and other vegetable crops (Jackson et al. 2012; Keinath 2007; Kousik et al. 2011; Matheron and Porchas 2000a, 2000b, 2015; Meyer and Hausbeck 2013; Tamietti and Valentino 2001).

Although resistance in $P$. capsici populations to the above mentioned newer fungicides has not been documented, it is known that this pathogen has the ability to develop fungicide resistance. Resistance to mefenoxam has been reported in various vegetable-producing regions (Café-Filho and Ristaino 2008; Dunn et al. 2010; Gevens et al. 2007; Jackson et al. 2010; Keinath 2007; Lamour and Hausbeck 2000), and more recent research has documented $P$. capsici isolates resistant to cyazofamid in the southeastern United States (Jackson et al. 2012; Kousik and Keinath 2008). Hence, it is highly desirable to identify 
new fungicides with different mode of actions to be used in integrated fungicide programs. Oxathiapiprolin is a new fungicide in the isoxazoline class recently developed by DuPont (Wilmington, DE) that inhibits oxysterol-binding proteins (Cohen 2015; Shepherd et al. 2013). It suppressed asexual life stages of $P$. capsici at lower concentrations than other fungicides targeting oomycete pathogens and reduced Phytophthora blight on bell pepper significantly under field conditions in Georgia (Ji and Csinos 2015). It is unknown whether oxathiapiprolin translocates in pepper plants and provides systemic protection of pepper foliage when applied to the root system. The objectives of this research were to develop a sensitive method to detect oxathiapiprolin in pepper plant tissues and determine whether the compound could move from pepper roots to the foliage. Understanding properties of the fungicide such as its movement in pepper plants will provide valuable information guiding design of application methods of the fungicide for more effective disease management.

\section{Materials and Methods}

Detection of oxathiapiprolin by HPLC. Oxathiapiprolin ( $\geq 99 \%$ purity), provided by DuPont, was dissolved in $1 \%$ formic acid in acetonitrile (vol/vol) at concentrations of $1,5,10,25,50,100$, and $500 \mu \mathrm{g} / \mathrm{ml}$. The solutions were placed in $1.5-\mathrm{ml}$ screw vials (Thermo Scientific, Waltham, MA), with three replicates for each concentration. Analysis was performed by a high-performance liquid chromatography (HPLC) system (Waters 2695; GMI Inc., Ramsey, MN) with a diode-array detector (Waters 2996), an autosampler, and an Empower 3 analytical workstation. Separation was conducted using a XTerra RP $\mathrm{C}_{18}$ column $(5 \mu \mathrm{m}, 4.6$ by $150 \mathrm{~mm}$; Restek Corp., Bellefonte, PA). Mobile phases A (acetonitrile) and B ( $0.1 \%$ formic acid in water) $(45: 55, \mathrm{vol} / \mathrm{vol})$ were used with a flow rate of $0.8 \mathrm{ml} / \mathrm{min}$ in the isocratic elution. Analytical wavelengths of 240,260 , and $280 \mathrm{~nm}$ were compared in preliminary studies, and $260 \mathrm{~nm}$, which yielded the best detection, was used in the following studies. Concentrations of oxathiapiprolin were calculated based on the areas of chromatographic peaks, as described below. Limits of detection and quantification were calculated using the methods reported previously (Luo et al. 2015).

Detection of oxathiapiprolin in plant tissues. To determine whether oxathiapiprolin could be selectively detected in plant tissues, bell pepper ('Aristotle') was grown from seed in 8.5 -cm pots containing a commercial potting mix (Scotts Miracle-Gro Co., Marysville, $\mathrm{OH})$ under greenhouse conditions. A randomized complete block design was employed with three replicates. Seedlings at the six- to seven-leaf growth stage, three from each replicate, were removed from pots to be used for treatment with oxathiapiprolin, and three for untreated control. Roots were washed under running tap water to remove soil, rinsed three times with sterile distilled water (SDW), and dried with sterile paper towels. Plant tissues, including root, stem ( $1 \mathrm{~cm}$ from the soil line), cotyledon, and leaf of the three plants from each replicate, were mixed, and approximately $1.0 \mathrm{~g}$ of each plant tissue was weighed and placed in a mortar. Oxathiapiprolin was dissolved in $1 \%$ formic acid in acetonitrile at $12 \mu \mathrm{g} / \mathrm{ml}$ and $0.25 \mathrm{ml}$ of the solution was added to plant tissue in the mortar and ground in liquid nitrogen. Plant tissues were transferred to $15-\mathrm{ml}$ plastic tubes and extraction of oxathiapiprolin followed the methods described previously, with minor modifications (Wu et al. 2014). Briefly, $0.75 \mathrm{ml}$ of formic acid aqueous solution $(1 \%, \mathrm{vol} / \mathrm{vol})$ and $2 \mathrm{ml} \mathrm{MeCN}$ were added in each tube and vortexed for $3 \mathrm{~min}$. $\mathrm{NaCl}(0.6 \mathrm{~g})$ was added to the tube $30 \mathrm{~min}$ later, and the tubes were vortexed for $1 \mathrm{~min}$ and centrifuged at $4,000 \mathrm{rpm}$ for $10 \mathrm{~min}$. The supernatant $(1.5 \mathrm{ml})$ was transferred to $2.0-\mathrm{ml}$ dispersive solid-phase extraction tubes (Fisher Scientific, Milford, MA) containing $50 \mathrm{mg}$ of $\mathrm{C}_{18}, 50 \mathrm{mg}$ of graphitized carbon black, $50 \mathrm{mg}$ of primary-secondary amine, and $150 \mathrm{mg}$ of $\mathrm{MgSO}_{4}$. The tubes were vortexed for $1 \mathrm{~min}$ and centrifuged at 10,000 rpm for $15 \mathrm{~min}$. The supernatants were filtered through $0.45-\mu \mathrm{m}$ nylon syringe filter (Restek Corp.) and analyzed by HPLC, as described above.

Determination of recovery and stability of oxathiapiprolin. Determination of recovery and stability of oxathiapiprolin was conducted using the methods by Wu et al. (2014), with modifications. Pepper seedlings were grown in the greenhouse as mentioned above and a randomized complete block design with three replicates was employed. Plant tissues were taken as described above and approximately $1.0 \mathrm{~g}$ of tissue was placed in a mortar. Solutions of oxathiapiprolin at 12,120 , and $1,200 \mu \mathrm{g} / \mathrm{ml}$ were prepared as above and $0.25 \mathrm{ml}$ of the solution was added to plant tissues in the mortar and ground in liquid nitrogen. Oxathiapiprolin was extracted from plant tissues and analyzed by HPLC as described above, with six injections of each sample. Percentage of recovery of oxathiapiprolin was calculated by comparing the quantities in plant tissues determined by HPLC with the known quantities of the compound added to the plant tissues. Relative standard deviation of the recovery rates was calculated as reported previously (Zhang et al. 2016). To determine stability of the compound in extracted samples, the samples were kept at $4^{\circ} \mathrm{C}$ for 5 days. Samples were analyzed by HPLC every day on five consecutive days and percentage of recovery was calculated as described above.

Translocation of oxathiapiprolin from roots to foliage of pepper in hydroculture. Pepper plants were grown and prepared as described above. QGU42 (active ingredient $=10 \%$ oxathiapiprolin) was provided by DuPont and a solution of oxathiapiprolin was prepared at $100 \mu \mathrm{g} / \mathrm{ml}$ in SDW. The roots of a seedling were placed in a 250-ml plastic bottle containing $125 \mathrm{ml}$ of oxathiapiprolin solution, with roots submerged in the solution. Roots placed in bottles containing $125 \mathrm{ml}$ of SDW were used as a control. The plants were incubated in a growth chamber at $23 \pm 1{ }^{\circ} \mathrm{C}$ with a 12 -h photoperiod. A randomized complete block design was employed with five replicates. A pepper seedling from each replicate was taken for analysis at $0,4,8,12,24,48,72,96,120$, and $144 \mathrm{~h}$ after placing roots in the fungicide solution. Plant tissues taken for analysis included the root, stem, cotyledon, first leaf, second leaf, and top leaf. Approximately $1.0 \mathrm{~g}$ of each plant tissue was taken, weighed, and ground separately in a mortar with liquid nitrogen. Extraction of oxathiapiprolin followed the methods described above and extracted samples were kept at $4{ }^{\circ} \mathrm{C}$ and analyzed by HPLC within 3 days.

Translocation of oxathiapiprolin from roots to foliage of pepper under greenhouse conditions. Pepper seedlings (Aristotle) were grown from seed in pots containing a potting mix in a greenhouse, as described earlier. QGU42 was diluted in SDW and $20 \mathrm{ml}$ of fungicide solution ( 100 or $400 \mu \mathrm{g} / \mathrm{ml}$ ) was applied by soil drench to a pepper plant at the six- to seven-leaf stage. Plants receiving $20 \mathrm{ml}$ of SDW were used as a control. A randomized complete block design was employed with four replicates.

To prepare zoospores of P. capsici, isolate PPC7 (Yin et al. 2012) was grown on $\mathrm{V} 8$ juice agar plates sealed with parafilm at $25^{\circ} \mathrm{C}$ for 5 days. The plates with parafilm removed were placed under continuous light at $25^{\circ} \mathrm{C}$ for $48 \mathrm{~h}$, and $10 \mathrm{ml}$ of SDW was added to each plate. Sporangia were induced to release zoospores by chilling at $4^{\circ} \mathrm{C}$ for $20 \mathrm{~min}$ and sitting at room temperature $\left(22 \pm 1^{\circ} \mathrm{C}\right)$ for $20 \mathrm{~min}$. Zoospore suspension was adjusted to $5 \times 10^{2}$ spores $/ \mathrm{ml}$ by observing with a hemocytometer.

Three days after fungicide application, zoospore suspension was applied to foliage of pepper plants $(10 \mathrm{ml} / \mathrm{plant})$ with a handheld sprayer. Soil in the pots was covered by sterile aluminum foil to prevent contact of zoospore suspension with the soil. The plants were incubated in a moisture chamber ( $>95 \%$ relative humidity) for $24 \mathrm{~h}$, aluminum foil was removed, and the plants were then kept in a greenhouse at $20^{\circ} \mathrm{C}$ (night) to $28^{\circ} \mathrm{C}$ (day). Three plants were taken from each replicate for each treatment $3,6,14$, and 21 days after fungicide application. Approximately $1.0 \mathrm{~g}$ of each plant tissue (i.e., root, stem, first leaf, and top leaf) was used for extraction and analysis of oxathiapiprolin using the methods described above.

Evaluation of Phytophthora blight severity. Development of Phytophthora blight was assessed 3, 6, 10, 14, 17, and 21 days after fungicide application. Disease incidence was quantified as percent diseased plants. Disease severity was evaluated using a 0-to-5 scale (Yin et al. 2012), where $0=$ no visible symptoms; $1=\leq 50 \%$ of stem with lesions or $\leq 50 \%$ of leaves wilted; $2=>50 \%$ of stem with lesions or $>50 \%$ of leaves wilted; $3=\leq 50 \%$ of stem with lesions and $>50 \%$ of leaves wilted, or $>50 \%$ of stem with lesions and $\leq 50 \%$ of leaves wilted; $4=>50 \%$ of stem with lesions and $>50 \%$ of leaves wilted; and $5=$ dead plant. Area under the disease progress 
curve (AUDPC) was calculated based on disease severity using the method published previously (Shaner and Finney 1977). Diseased plants from each treatment were taken for isolation of causal agent on PARPH medium, and isolates were identified by morphological characteristics and polymerase chain reaction analysis using $P$. capsicispecific primers (Yin et al. 2012).

Statistical analysis. All experiments were conducted twice under the same conditions. In the lab experiments to detect different concentrations of oxathiapiprolin (1 to $500 \mu \mathrm{g} / \mathrm{ml}$ ) by HPLC, linear regression analysis was conducted using Microsoft Excel (v15.0) to determine linearity of calibration curves of the various concentrations of oxathiapiprolin and coefficient of determination $\left(R^{2}\right)$. Linear regression equation was established to describe the relationship between concentrations of oxathiapiprolin and areas of chromatographic peaks. Data from the hydroculture and greenhouse experiments were analyzed using the general linear model procedures of the Statistical Analysis System (SAS Institute, Cary, NC), and differences among the means of the treatments were separated by Fisher's protected least significant difference test at $P<0.05$.

\section{Results}

Detection, recovery, and stability of oxathiapiprolin. The relationship between concentrations of oxathiapiprolin $(y)$ and areas of chromatographic peaks $(x)$ was best described by the linear regression equation $y=19,423 x+1,370.2$, in an oxathiapiprolin concentration range from 1 to $500 \mu \mathrm{g} / \mathrm{ml}\left(R^{2}=0.9999\right)$. Limits of detection and quantification were 0.001 and $0.15 \mu \mathrm{g} / \mathrm{ml}$, respectively. No interferences appeared around the retention time of oxathiapiprolin (approximately $7.1 \mathrm{~min}$ ) in the untreated control pepper samples (roots, stems, and leaves) or pepper samples with oxathiapiprolin added (Fig. 1). Oxathiapiprolin was not detected in the untreated control samples. Recovery rates of oxathiapiprolin from plant tissues were calculated by comparing the quantities in plant tissues determined by HPLC with known quantities of the compound added to the plant tissues. Percent recovery of oxathiapiprolin from treated samples ranged from 97.0 to $118.7 \%$ and 87.0 to $119.3 \%$ when the samples were analyzed within a day and daily for 5 days, respectively (Table 1). Relative standard deviations of the recovery rates were 1.1 to $5.5 \%$, which were regarded as satisfactory (Zhang et al. 2016).

Translocation of oxathiapiprolin from roots to foliage of pepper in hydroculture. Movement of oxathiapiprolin from root to foliage was assayed at different time intervals after treatment. The compound was detected in the roots $4 \mathrm{~h}$ after treatment with an amount of $18.5 \mu \mathrm{g} / \mathrm{g}$ of root (Table 2). The quantity was the highest at $48 \mathrm{~h}(120.1 \mu \mathrm{g} / \mathrm{g}$ of root) and it was still detectable at $144 \mathrm{~h}$ (23.2 $\mu \mathrm{g} / \mathrm{g}$ of root). Oxathiapiprolin was detected in the stem,

Table 1. Recovery and stability of oxathiapiprolin added to pepper plant tissues $^{\mathrm{w}}$

\begin{tabular}{|c|c|c|c|c|}
\hline \multirow[b]{2}{*}{$\operatorname{Conc}(\mu \mathrm{g} / \mathrm{ml})^{\mathrm{z}}$} & \multicolumn{2}{|c|}{ Analysis within a day } & \multicolumn{2}{|c|}{ Analysis in 5 days $^{y}$} \\
\hline & Recovery (\%) & $\overline{\text { RSD }(\%)}$ & Recovery (\%) & RSD (\%) \\
\hline 1 & 97.0 & 4.0 & 87.0 & 2.9 \\
\hline 10 & 118.7 & 1.1 & 93.6 & 2.1 \\
\hline 100 & 100.8 & 5.5 & 119.3 & 3.1 \\
\hline
\end{tabular}

${ }^{w}$ Percent recovery of oxathiapiprolin was amount detected in the samples in comparison with the amount added to the plant tissues. RSD = relative standard deviation of the means calculated as reported previously (Zhang et al. 2016).

x Samples were treated with oxathiapiprolin and analyzed in the same day.

y Samples were treated with oxathiapiprolin and analyzed daily on five consecutive days (kept at $4^{\circ} \mathrm{C}$ ).

${ }^{\mathrm{z}}$ Concentrations of oxathipiprolin added to pepper plant tissues.
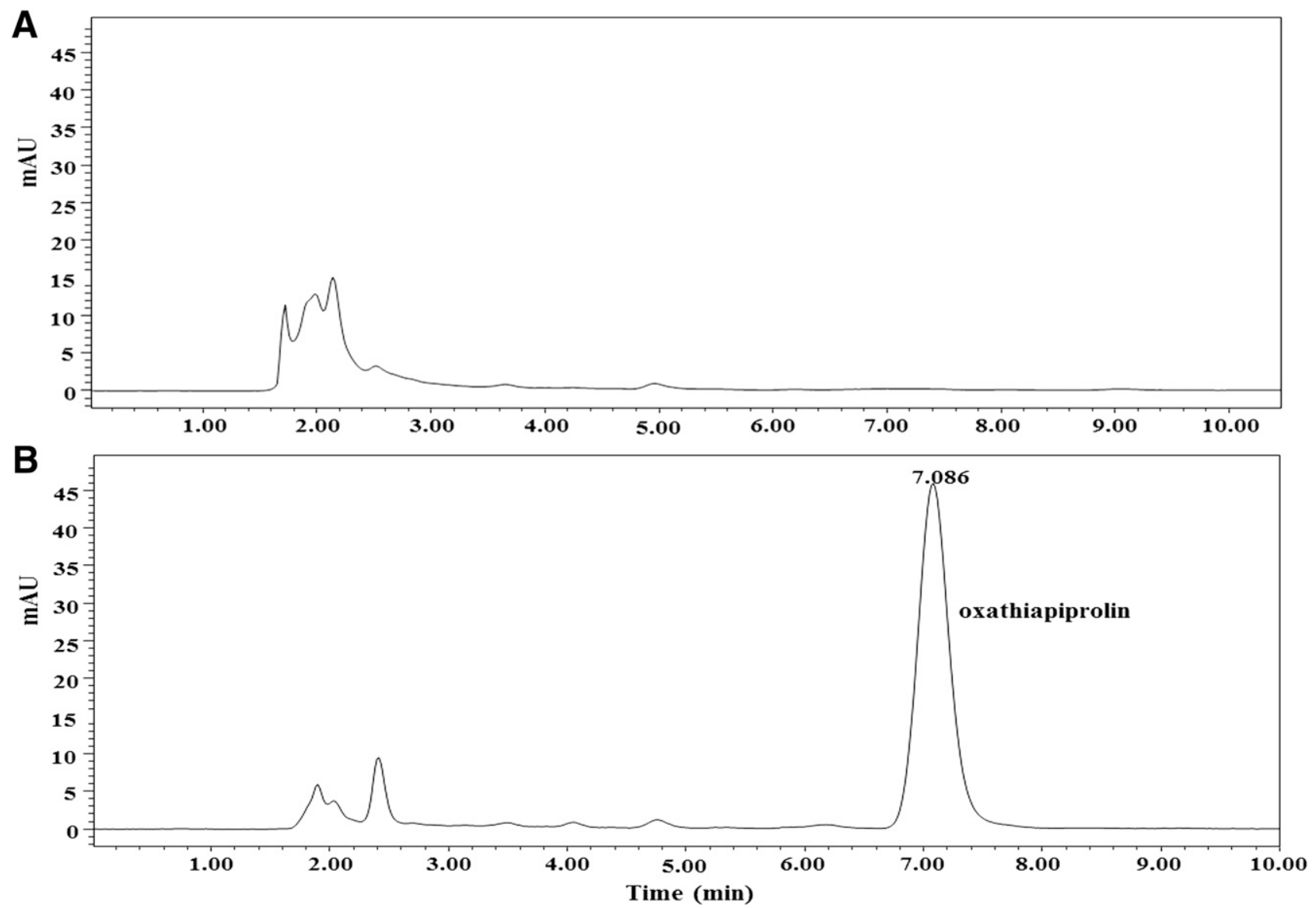

Fig. 1. High-performance liquid chromatography chromatograms of oxathiapiprolin extracted from pepper plant. A, Untreated control plant without oxathiapiprolin and B, plant treated with oxathiapiprolin. 
cotyledon, first true leaf, and second true leaf $8 \mathrm{~h}$ after treatment with lower amounts compared with the root, that ranged from $0.6 \mu \mathrm{g} / \mathrm{g}$ of cotyledon to $1.7 \mu \mathrm{g} / \mathrm{g}$ of stem. The compound was detectable in all four foliar tissues within $144 \mathrm{~h}$ after treatment, with relatively higher amounts in the stem, first true leaf, and second true leaf at $48 \mathrm{~h}$. The compound was not detected in the top leaves until $48 \mathrm{~h}$ after treatment and was detected from 48 to $144 \mathrm{~h}$, ranging from 1.0 to $3.9 \mu \mathrm{g} / \mathrm{g}$ of tissue. Oxathiapiprolin was not detected in the untreated control samples.

Translocation of oxathiapiprolin from roots to foliage of pepper under greenhouse conditions. Oxathiapiprolin was detectable in the roots $3,6,14$, and 21 days after soil drench with the product in greenhouse. The amounts in the roots did not change over the 21-day period, ranging from 0.6 to $0.8 \mu \mathrm{g} / \mathrm{g}$ of root when oxathiapiprolin was applied at $100 \mu \mathrm{g} / \mathrm{ml}$, and from 0.7 to $0.8 \mu \mathrm{g} / \mathrm{g}$ of root when applied at $400 \mu \mathrm{g} / \mathrm{ml}$ (Table 3). The compound was detected in the stem and first true leaf 6 days after soil drench, with an amount of 0.6 to $0.9 \mu \mathrm{g} / \mathrm{g}$ in stem tissue and $0.6 \mu \mathrm{g} / \mathrm{g}$ in leaf tissue at 6 to 21 days when applied at $100 \mu \mathrm{g} / \mathrm{ml}$. It was detected in the top leaves only at day $21(0.6 \mu \mathrm{g} / \mathrm{g}$ of leaf) when applied at $100 \mu \mathrm{g} / \mathrm{ml}$. When oxathiapiprolin was applied at $400 \mu \mathrm{g} / \mathrm{ml}$, it was detected in the stem, first leaf, and top leaf within 3 days of application and was still detectable 21 days after application, with amounts ranging from 0.8 to $1.2 \mu \mathrm{g} / \mathrm{g}$ of stem and 0.6 to $1.1 \mu \mathrm{g} / \mathrm{g}$ of leaf. No oxathiapiprolin was detected in the untreated control plants.

Evaluation of Phytophthora blight severity. Microorganisms isolated from symptomatic plants on PARPH were morphologically identified as $P$. capsici, with confirmation by molecular identification. Application of oxathiapiprolin by soil drench reduced Phytophthora blight on pepper foliage significantly when zoospore suspension of $P$. capsici was applied to the foliage. Disease incidences were 22.2 and $16.7 \%$ when the product was applied at 100 and $400 \mu \mathrm{g} / \mathrm{ml}$, respectively, which were significantly lower compared with the untreated control (Table 4). AUDPC values were also reduced significantly when it was applied at 100 or $400 \mu \mathrm{g} / \mathrm{ml} \mathrm{com-}$ pared with the control. There was no significant difference in disease reduction when oxathiapiprolin was applied at 100 or $400 \mu \mathrm{g} / \mathrm{ml}$.

\section{Discussion}

Oxathiapiprolin is a new fungicide for control of oomycete pathogens and was first registered by Syngenta Crop Protection for commercial use in the United States in 2015 (trade name: Orondis). This compound inhibited mycelial growth, sporangial production, and zoospore germination of $P$. capsici isolates at low concentrations (Ji and Csinos 2015). In field studies conducted in Georgia, oxathiapiprolin applied through drip irrigation or by soil drench plus foliar sprays reduced Phytophthora blight on bell pepper significantly ( $\mathrm{Ji}$ and Csinos 2015). It was unknown if this compound could translocate systemically in pepper plants. Experiments conducted in this report indicated that oxathiapiprolin moved from roots to stems and leaves of pepper plants, and application of the compound to pepper roots reduced Phytophthora blight on the foliage significantly.

Previous studies indicated that oxathiapiprolin was effective in suppression of oomycete pathogens. It inhibited zoospore release, cystospore germination, sporangiophore development, and sporangial production of Pseudoperonospora cubensis, causal agent of downy mildew of cucurbits (Cohen 2015). In assays using detached leaves of cucurbits, oxathiapiprolin inhibited formation and expansion of lesions on the leaves caused by $P$. cubensis. In another study, foliar applications of oxathiapiprolin reduced downy mildew on basil caused by Peronospora belbahrii under greenhouse and field conditions (Patel et al. 2015). In greenhouse studies, seed treatment with oxathiapiprolin significantly reduced downy mildew severity on cucumber and basil (Cohen 2015; Patel et al. 2015). Field studies conducted in 2011 to 2013 in Georgia indicated that oxathiapiprolin

Table 3. Translocation of oxathiapiprolin in pepper plants following soil drench in greenhouse studies

\begin{tabular}{lrlllc}
\hline \multirow{2}{*}{$\begin{array}{l}\text { Conc } \\
(\boldsymbol{\mu g} / \mathbf{m l})^{\mathbf{y}}\end{array}$} & \multicolumn{4}{c}{ Oxathiapiprolin in plant tissue $(\boldsymbol{\mu g} / \mathbf{g})^{\mathbf{x}}$} \\
\cline { 3 - 6 } & Days $^{\mathbf{z}}$ & \multicolumn{1}{c}{ Root } & \multicolumn{1}{c}{ Stem } & \multicolumn{1}{c}{ First leaf } & Top leaf \\
\hline 100 & 3 & $0.7 \pm 0.0 \mathrm{fghi}$ & $\mathrm{ND}$ & $\mathrm{ND}$ & $\mathrm{ND}$ \\
& 6 & $0.8 \pm 0.1 \mathrm{efg}$ & $0.6 \pm 0.0 \mathrm{i}$ & $0.6 \pm 0.0 \mathrm{i}$ & $\mathrm{ND}$ \\
& 14 & $0.6 \pm 0.0 \mathrm{hi}$ & $0.9 \pm 0.3 \mathrm{de}$ & $0.6 \pm 0.0 \mathrm{i}$ & $\mathrm{ND}$ \\
& 21 & $0.6 \pm 0.0 \mathrm{i}$ & $0.6 \pm 0.0 \mathrm{i}$ & $0.6 \pm 0.0 \mathrm{i}$ & $0.6 \pm 0.0 \mathrm{i}$ \\
& 3 & $0.7 \pm 0.1 \mathrm{fgh}$ & $1.1 \pm 0.5 \mathrm{bc}$ & $0.6 \pm 0.0 \mathrm{i}$ & $0.6 \pm 0.0 \mathrm{i}$ \\
& 6 & $0.8 \pm 0.0 \mathrm{efg}$ & $1.2 \pm 0.4 \mathrm{ab}$ & $1.0 \pm 0.3 \mathrm{~cd}$ & $0.6 \pm 0.0 \mathrm{i}$ \\
& 14 & $0.8 \pm 0.1 \mathrm{ef}$ & $1.2 \pm 0.6 \mathrm{a}$ & $1.1 \pm 0.3 \mathrm{bc}$ & $0.6 \pm 0.0 \mathrm{i}$ \\
& 21 & $0.8 \pm 0.1 \mathrm{ef}$ & $0.8 \pm 0.1 \mathrm{ef}$ & $0.6 \pm 0.0 \mathrm{i}$ & $0.6 \pm 0.0 \mathrm{i}$ \\
\hline
\end{tabular}

${ }^{x}$ Values are means of four replicates \pm standard errors of the means. Values followed by the same letters indicate no significant difference $(P=0.05)$. $\mathrm{ND}=$ not detected in samples $(<0.41 \mu \mathrm{g} / \mathrm{g})$.

${ }^{y}$ Concentrations of oxathipiprolin used for soil drench.

z Time (days) after application of oxathiapiprolin.

Table 4. Efficacy of soil drench with oxathiapiprolin for reduction of Phytophthora blight on pepper foliage under greenhouse conditions ${ }^{\mathrm{w}}$

\begin{tabular}{lcc}
\hline Concentration $(\boldsymbol{\mu g} / \mathbf{m l})^{\mathbf{x}}$ & ${\text { Incidence }(\%))^{\mathbf{y}}}$ & AUDPC $^{\mathbf{z}}$ \\
\hline 0 & $86.1 \pm 6.3 \mathrm{a}$ & $717 \pm 38 \mathrm{a}$ \\
100 & $22.2 \pm 7.0 \mathrm{~b}$ & $84 \pm 29 \mathrm{~b}$ \\
400 & $16.7 \pm 7.5 \mathrm{~b}$ & $52 \pm 18 \mathrm{~b}$ \\
\hline
\end{tabular}

${ }^{w}$ Values are means of four replicates \pm standard errors of the means. Values followed by the same letters indicate no significant difference $(P=0.05)$.

$x$ Concentrations of oxathipiprolin used for soil drench.

y Final disease incidence (percent diseased plants).

$\mathrm{z}$ Area under the disease progress curve.

Table 2. Translocation of oxathiapiprolin in pepper plant in hydroculture after application to the root

\begin{tabular}{|c|c|c|c|c|c|c|}
\hline \multirow[b]{2}{*}{ Time $(\mathbf{h})^{\mathrm{z}}$} & \multirow[b]{2}{*}{ Root } & \multicolumn{4}{|c|}{ Oxathiapiprolin in plant tissue $(\mu \mathrm{g} / \mathrm{g})^{\mathrm{y}}$} & \multirow[b]{2}{*}{ Top leaf } \\
\hline & & Stem & Cotyledon & First leaf & Second leaf & \\
\hline 0 & ND & ND & ND & ND & ND & ND \\
\hline 4 & $18.5 \pm 1.3 \mathrm{f}$ & ND & ND & ND & ND & ND \\
\hline 8 & $30.4 \pm 9.2 \mathrm{de}$ & $1.7 \pm 0.2 \mathrm{i}$ & $0.6 \pm 0.4 \mathrm{i}$ & $0.9 \pm 0.1 \mathrm{i}$ & $0.8 \pm 0.1 \mathrm{i}$ & ND \\
\hline 12 & $37.7 \pm 5.0 \mathrm{~d}$ & $3.0 \pm 1.4 \mathrm{hi}$ & $1.0 \pm 0.7 \mathrm{i}$ & $0.9 \pm 0.2 \mathrm{i}$ & $0.9 \pm 0.1 \mathrm{i}$ & ND \\
\hline 24 & $86.7 \pm 8.5 \mathrm{~b}$ & $3.1 \pm 1.2 \mathrm{hi}$ & $1.6 \pm 1.3 \mathrm{i}$ & $1.4 \pm 0.1 \mathrm{i}$ & $1.2 \pm 0.2 \mathrm{i}$ & ND \\
\hline 48 & $120.1 \pm 13.5 \mathrm{a}$ & $7.5 \pm 1.0 \mathrm{~g}$ & $1.8 \pm 0.7 \mathrm{i}$ & $2.5 \pm 1.3 \mathrm{hi}$ & $4.4 \pm 1.6 \mathrm{~h}$ & $3.9 \pm 2.1 \mathrm{hi}$ \\
\hline 72 & $54.6 \pm 15.8 \mathrm{c}$ & $2.9 \pm 1.3 \mathrm{hi}$ & $1.8 \pm 0.1 \mathrm{i}$ & $1.1 \pm 0.0 \mathrm{i}$ & $1.1 \pm 0.2 \mathrm{i}$ & $1.2 \pm 0.1 \mathrm{i}$ \\
\hline 96 & $37.9 \pm 6.5 \mathrm{~d}$ & $3.0 \pm 2.8 \mathrm{hi}$ & $1.4 \pm 0.2 \mathrm{i}$ & $1.2 \pm 0.1 \mathrm{i}$ & $1.7 \pm 0.8 \mathrm{i}$ & $1.4 \pm 0.4 \mathrm{i}$ \\
\hline 120 & $31.3 \pm 10.5 \mathrm{~d}$ & $1.3 \pm 0.0 \mathrm{i}$ & $1.1 \pm 0.1 \mathrm{i}$ & $1.0 \pm 0.1 \mathrm{i}$ & $1.4 \pm 0.7 \mathrm{i}$ & $1.7 \pm 0.7 \mathrm{i}$ \\
\hline 144 & $23.2 \pm 11.7 \mathrm{ef}$ & $2.3 \pm 0.9 \mathrm{i}$ & $1.2 \pm 0.1 \mathrm{i}$ & $1.0 \pm 0.2 \mathrm{i}$ & $1.0 \pm 0.1 \mathrm{i}$ & $1.0 \pm 0.5 \mathrm{i}$ \\
\hline
\end{tabular}

${ }^{y}$ Values are means of five replicates \pm standard errors of the means. Values followed by the same letters indicate no significant difference $(P=0.05)$. ND $=$ not detected in samples $(<0.41 \mu \mathrm{g} / \mathrm{g})$.

$\mathrm{z}$ Time (h) after application of oxathiapiprolin. 
applied through transplant water and directed sprays significantly reduced black shank of tobacco caused by Phytophthora nicotianae ( $\mathrm{Ji}$ et al. 2014). In a study on chili pepper, plant mortality caused by $P$. capsici was significantly decreased in greenhouse trials with soil applications of oxathiapiprolin; however, oxathiapiprolin did not significantly reduce final plant mortality in field trials (Matheron and Porchas 2015). Ineffective disease suppression observed in the field may be due to lack of efficient movement of oxathiapiprolin in the soil to the root zone when applied by furrow irrigation (Matheron and Porchas 2015).

Systemic movement of oxathiapiprolin in plants was assayed indirectly in cucumber (Cohen 2015). In studies with detached cucumber leaves, oxathiapiprolin applied to one side of the leaf reduced disease on the other side of the leaf. On cucumber grown in pots in a greenhouse, oxathiapiprolin spray applied to the first true leaf reduced downy mildew caused by $P$. cubensis on the second true leaf, and the compound applied as a soil drench to the roots of cucumber provided complete protection of the leaves against the disease (Cohen 2015). These studies indicated that oxathiapiprolin might translocate from leaves to leaves and from the root to the foliage of cucumber plants. The indirect method is easier and more convenient to use than direct detection by HPLC. However, the indirect method could not quantify how much oxathiapiprolin was translocated from one plant tissue to another. In addition, disease reduction by application of chemical compounds might be due to mechanisms such as induced plant systemic resistance; hence, it was uncertain whether oxathiapiprolin translocated in the plants in studies using the indirect methods. An analytical method for direct detection of oxathiapiprolin in plants was developed by Wu et al. (2014) using liquid chromatography coupled with tandem mass spectrometry. In the seven crop plants studied (cucumber, grape [Vitis vinifera], potato [S. tuberosum], tomato, watermelon, watermelon peel, and wheat [Triticum aestivum]), the limit of detection for oxathiapiprolin was $0.5 \mu \mathrm{g} /$ liter. Percent recoveries of oxathiapiprolin from tissues of the seven crops ranged from 82.0 to $110.7 \%$. The analytical method also successfully detected two metabolites of oxathiapiprolin, IN-E8S72 and IN-WR791, in the plant tissues (Wu et al. 2014). IN-E8S72 and IN-WR791 did not show activities to suppress oomycete pathogens (C. P. Shepherd, personal communication).

Although direct detection of movement of oxathiapiprolin in plants was not reported previously, movement of some other fungicides used for control of oomycete pathogens was studied in a few crops. Fluopicolide could be absorbed by cucumber roots from aqueous solutions but it was not detected in cucumber roots after spray application to the leaves (Rupprecht 2007). In a study on tomato, fluopicolide applied to soil was absorbed by tomato roots and then translocated to the stems and leaves. It was detected in tomato roots for more than 30 days and in leaves and stems 20 days after application (Jiang et al. 2015). In tomato, $20 \%$ fosetyl-Al translocated from the roots to the foliar parts $3 \mathrm{~h}$ after application, and the quantities of the fungicide in roots and foliar parts were similar after $72 \mathrm{~h}$ (Leconte et al. 1988). In translocation research using ${ }^{14} \mathrm{C}$-metalaxyl in tomato and other plants, the fungicide moved from lower to upper leaves and vice versa (Zaki et al. 1981). It was translocated laterally and upward to the leaves after the fungicide was absorbed by the stem. A minor proportion of the labeled fungicide was detected in the root after application to the leaf or stem (Zaki et al. 1981).

The present study is the first report to directly detect translocation of oxathiapiprolin in plants. Wu et al. (2014) conducted research to recover oxathiapiprolin from a few plants other than pepper but did not detect translocation of the compound in the plants. The limit of detection was $0.001 \mu \mathrm{g} / \mathrm{ml}$ and average recoveries from pepper plant samples ranged from 87.0 to $119.3 \%$ in the present study, which were similar to the detection limit and recovery rates in other plants studied (Wu et al. 2014). The detection method was able to sensitively detect oxathiapiprolin when it was applied to pepper plant tissues in lab studies or applied to the roots of potted pepper plants under greenhouse conditions. In greenhouse studies, oxathiapiprolin was detected in pepper stems and leaves at 0.6 to $1.1 \mu \mathrm{g} / \mathrm{g}$ of tissue after application of the compound to the roots. The amount of oxathiapiprolin in the pepper plant tissues should be high enough to suppress asexual life stages of $P$. capsici since the dose of the compound at which $50 \%$ inhibition occurs for inhibiting mycelial growth, sporangial production, and zoospore germination of $P$. capsici isolates averaged 0.001, 0.0003, and $0.54 \mu \mathrm{g} / \mathrm{ml}$, respectively ( $\mathrm{Ji}$ and Csinos 2015). This coincided with the significant disease reduction on the foliage when oxathiapiprolin was applied to the soil and root in the greenhouse studies. In the studies with potted plants, oxathiapiprolin was detected at lower quantities in plant tissues than in the hydroculture studies. This was probably due to absorption of oxathiapiprolin by the potting mix used in the studies. Further studies could be conducted in greenhouse and field settings to evaluate the effects of different soil types on absorption and translocation of oxathiapiprolin. In research to determine translocation of oxathiapiprolin from roots to foliage of pepper in hydroculture, oxathiapiprolin at 1.8 to $120 \mu \mathrm{g} / \mathrm{g}$ of tissue was detected in plant samples $48 \mathrm{~h}$ after application of the compound to the roots. Quantities of oxathiapiprolin in plant tissues declined after $48 \mathrm{~h}$. Although this may be related to plant metabolism, the reason for the decline is uncertain and remains to be elucidated. Further research can also be conducted to detect whether oxathiapiprolin moves from pepper foliage to the roots, and its translocation in other crops susceptible to $P$. capsici. These studies will provide a more comprehensive understanding of oxathiapiprolin plant activity, which can be valuable for developing more effective or economical fungicide application methods for managing Phytophthora blight on vegetables.

\section{Acknowledgments}

We thank DuPont Crop Protection for providing products used in the study, and the United States Department of Agriculture National Institute of Food and Agriculture and Georgia Commodity Commission for Vegetables for their support.

\section{Literature Cited}

Café-Filho, A. C., and Ristaino, J. B. 2008. Fitness of isolates of Phytophthora capsici resistant to mefenoxam from squash and pepper fields in North Carolina. Plant Dis. 92:1439-1443.

Cerkauskas, R. F., Ferguson, G., and MacNair, C. 2015. Management of Phytophthora blight (Phytophthora capsici) on vegetables in Ontario: Some greenhouse and field aspects. Can. J. Plant Pathol. 37:285-304.

Cohen, Y. 2015. The novel oomycide oxathiapiprolin inhibits all stages in the asexual life cycle of Pseudoperonospora cubensis-Causal agent of cucurbit downy mildew. PLoS One 10:e0140015.

Dunn, A. R., Milgroom, M. G., Meitz, J. C., McLeod, A., Fry, W. E., McGrath, M. T., Dillard, H. R., and Smart, C. D. 2010. Population structure and resistance to mefenoxam of Phytophthora capsici in New York State. Plant Dis. 94:1461-1468.

Dunn, A. R., Wyatt, L. E., Mazourek, M., Reiners, S., and Smart, C. D. 2013 Performance and tolerance to Phytophthora blight of bell pepper varieties. HortTechnology 23:382-390.

Erwin, D. C., and Ribeiro, O. K. 1996. Phytophthora Diseases Worldwide American Phytopathological Society Press, St. Paul, MN.

Foster, J. M., and Hausbeck, M. K. 2010. Managing Phytophthora crown and roo rot in bell pepper using fungicides and host resistance. Plant Dis. 94:697-702.

Gevens, A. J., Donahoo, R. S., Lamour, K. H., and Hausbeck, M. K. 2007. Characterization of Phytophthora capsici from Michigan surface irrigation water. Phytopathology 97:421-428.

Hausbeck, M. K., and Lamour, K. H. 2004. Phytophthora capsici on vegetable crops: Research progress and management challenges. Plant Dis. 88:1292-1303.

Jackson, K. L., Yin, J., Csinos, A. S., and Ji, P. 2010. Fungicidal activity of fluopicolide for suppression of Phytophthora capsici on squash. Crop Prot 29:1421-1427.

Jackson, K. L., Yin, J., and Ji, P. 2012. Sensitivity of Phytophthora capsici on vegetable crops in Georgia to mandipropamid, dimethomorph, and cyazofamid Plant Dis. 96:1337-1342.

Ji, P., and Csinos, A. S. 2015. Effect of oxathiapiprolin on asexual life stages of Phytophthora capsici and disease development on vegetables. Ann. Appl. Biol. 166:229-235

Ji, P., Csinos, A. S., Hickman, L. L., and Hargett, U. 2014. Efficacy and application methods of oxathiapiprolin for management of black shank on tobacco. Plant Dis. 98:1551-1554

Ji, P., Yin, J., and Koné, D. 2011. Application of acibenzolar-S-methyl and standard fungicides for control of Phytophthora blight on squash. Crop Prot. 30:1601-1605.

Jiang, L. L., Wang, H. Y., Xu, H., Qiao, K., Xia, X. M., and Wang, K. Y. 2015. Transportation behaviour of fluopicolide and its control effect against Phytophthora capsici in greenhouse tomatoes after soil application. Pest Manage. Sci. 71:1008-1014. 
Keinath, A. P. 2007. Sensitivity of populations of Phytophthora capsici from South Carolina to mefenoxam, dimethomorph, zoxamide, and cymoxanil. Plant Dis. 91:743-748.

Keinath, A. P., and Kousik, C. S. 2011. Sensitivity of isolates of Phytophthora capsici from the eastern United States to fluopicolide. Plant Dis. 95:1414-1419.

Kousik, C. S., Adams, M. L., Jester, W. R., Hassell, R., Harrison, H. F., and Holmes, G. J. 2011. Effect of cultural practices and fungicides on Phytophthora fruit rot of watermelon in the Carolinas. Crop Prot. 30:888-894.

Kousik, C. S., and Keinath, A. P. 2008. First report of insensitivity to cyazofamid among isolates of Phytophthora capsici from the southeastern United States. Plant Dis. 92:979.

Krober, H. 1980. Survival of some Phytophthora species in soil. Z. Pflanzenkrankh. Pflanzenschutz 87:227-235.

Kuck, K.-H., and Gisi, U. 2008. FRAC mode of action classification and resistance risk of fungicides. Pages 415-432 in: Modern Crop Protection Compounds. W. Krämer and U. Schirmer, eds. Wiley-VCH Verlag GmbH \& Co. KGaA, Weinheim, Germany.

Kuhn, P. J., Pitt, D., Lee, S. A., Wakley, G., and Sheppard, A. N. 1991. Effects of dimethomorph on the morphology and ultrastructure of Phytophthora. Mycol. Res. 95:333-340.

Lamour, K. H., and Hausbeck, M. K. 2000. Mefenoxam insensitivity and the sexual stage of Phytophthora capsici in Michigan cucurbit fields. Phytopathology 90:396-400.

Leconte, F., Bonnemain, J. L., de Cormis, L., and Barchietto, T. 1988. The metabolic fate, distribution and forms of transport (xylem and phloem) of fosetyl-Al in Lycopersicon esculentum Mill.C. R. Acad. Sci. Ser. 3 Sci. Vie 307:221-227.

Luo, Z. Q., Deng, Z. Q., Liu, Y., Wang, G. P., Yang, W. N., Hou, C. B., Tang, M. M., Yang, R. R., and Zhou, H. M. 2015. Development and validation of a novel stability indicating HPLC method for the quantitative determination of eleven related substances in ezetimibe drug substance and drug product. Talanta 139:67-74.

Matheron, M. E., and Porchas, M. 2000a. Impact of azoxystrobin, dimethomorph, fluazinam, fosetyl-Al, and metalaxyl on growth, sporulation, and zoospore cyst germination of three Phytophthora spp. Plant Dis. 84:454-458.

Matheron, M. E., and Porchas, M. 2000b. Comparison of five fungicides on development of root, crown, and fruit rot of chile pepper and recovery of Phytophthora capsici from soil. Plant Dis. 84:1038-1043.

Matheron, M. E., and Porchas, M. 2015. Effectiveness of nine different fungicides for management of crown and root rot of chile pepper plants caused by Phytophthora capsici. Online publication. Plant Health Prog. doi:10.1094/ PHP-RS-15-0028

Meyer, M. D., and Hausbeck, M. K. 2013. Using soil-applied fungicides to manage Phytophthora crown and root rot on summer squash. Plant Dis. 97:107-112.
Patel, J. S., Costa de Novaes, M. I., and Zhang, S. 2015. Evaluation of the new compound oxathiapiprolin for control of downy mildew in basil. Online publication. Plant Health Prog. doi:10.1094/PHP-RS-15-0026

Rupprecht, J. K. 2007. Behaviour of fluopicolide in plants. Pflanzenschutz Nachr. Bayer 59:261-280.

Sanogo, S., and Ji, P. 2012. Integrated management of Phytophthora capsici on solanaceous and cucurbitaceous crops: Current status, gaps in knowledge, and research needs. Can. J. Plant Pathol. 34:479-492.

Sanogo, S., and Ji, P. 2013. Water management in relation to control of Phytophthora capsici in vegetable crops. Agric. Water Manage. 129:113-119.

Shaner, G., and Finney, R. E. 1977. The effect of nitrogen fertilization on the expression of slow-mildewing resistance in Knox wheat. Phytopathology 67: 1051-1056.

Shepherd, C. P., Bruhn, J. A., Carski, T. H., Summers, B., Hoffman, L. E., Perotin, B., and Sweigard, J. A. 2013. DuPont ${ }^{\mathrm{TM}}$ Zorvec $^{\mathrm{TM}}$ (DPX-QGU42, oxathiapiprolin): The first member of a novel class of Oomycete fungicides. Page 17 in: Abstr. 4th Int. Phytophthora capsici Conf. Duck Key, FL. A. S. Csinos and P. D. Roberts, eds.

Tamietti, G., and Valentino, D. 2001. Physiological characterisation of a population of Phytophthora capsici Leon. from Northern Italy. J. Plant Pathol. 83:199-205.

Toquin, V., Barja, F., Sirven, C., and Bffa, R. 2008. Fluopicolide, a new antioomycetes fungicide with a new mode of action inducing perturbation of a spectrin-like protein. Pages 675-682 in: Modern Crop Protection Compounds. W. Krämer and U. Schirmer, eds. Wiley-VCH Verlag GmbH \& Co. KGaA Weinheim, Germany.

Wang, Z., Langston, D. B., Csinos, A. S., Gitaitis, R. D., Walcott, R. R., and Ji, P. 2009. Development of an improved isolation approach and simple sequence repeat markers to characterize Phytophthora capsici populations in irrigation ponds in southern Georgia. Appl. Environ. Microbiol. 75:5467-5473.

Wu, X., Xu, J., Dong, F., Liu, X., Li, Y., and Zheng, Y. 2014. Simultaneous determination of oxathiapiprolin and two metabolites in fruits, vegetables and cereal using a modified quick, easy, cheap, effective, rugged, and safe method and liquid chromatography coupled to tandem mass spectrometry. J. Chromatogr. A 1329:30-37.

Yin, J., Jackson, K. L., Candole, B. L., Csinos, A. S., Langston, D. B., and Ji, P. 2012. Aggressiveness and diversity of Phytophthora capsici on vegetable crops in Georgia. Ann. Appl. Biol. 160:191-200

Zaki, A. I., Zentmyer, G. A., and LeBaron, H. M. 1981. Systemic translocation of ${ }^{14} \mathrm{C}$-labeled metalaxyl in tomato, avocado, and Persea indica. Phytopathology 71:509-514.

Zhang, D., Wu, L., Chow, D. S.-L., Tam, V. H., and Rios, D. R. 2016. Quantitative determination of dopamine in human plasma by a highly sensitive LC-MS/MS assay: Application in preterm neonates. J. Pharm. Biomed. Anal. 117:227-231. 